\title{
EFFECT OF LIME AND PHOSPHORUS ON THE YIELD OF FOUR LEGUMINOSAE IN TWO ACID SOILS OF PUERTO RICO
}

\author{
BY J. A. BONNET, E. A. TELFORD, F. MARIOTA AND P. TIRADO SULSONA ${ }^{1}$
}

\section{INTRODUCTION}

Conservation of soil nitrogen and organic matter is of paramount importance in the tropics. Although some Leguminosae grow well in the acid soils of the humid region of Puerto Rico it is believed that maximum yields of green manuring and maximum nitrogen fixation have not been obtained, in Puerto Rico, because little attention has been given to some practices which have a direct bearing on optimum growth of these plants. Among these practices, the application of lime to acid soils and the application of phosphorus to soils deficient in it are of importance.

EXPERIMENTAL WORK

Two one-acre fields of the soil type "Fajardo clay", at the Experiment Station farm in Río Piedras; and two of the soil type "Catalina clay" level phase, at "Las Ochenta" farm in Mayaguez, were chosen for the site of the experiment. Two fields were chosen at each place to study also the effect on the crop yield of sweet potatoes of two methods of incorporating the green manure. In field " $\mathrm{A}$ ", the green manure was turned-under with a hoe as done by small farmers. In field "B", it was plowed under with a tractor-driven plow as done by the large landowners.

"Fajardo clay" is an acid soil of the humid region derived from old, high alluvial material and from outwash fans of adjacent shale hills. The relief is level or gently sloping. In a cultivated field it has a granular-brown or reddish-brown, friable, clay surface about 9 inches thick, fairly easily penetrated by plant roots and percolating water. The upper few inches of the subsoil consists of distinctly heavier, mottled, deep-red and brown, mediumcompact clay, which slightly hinders the percolation of water and interferes with good development of roots. At a depth of about 14 inches, the soil material becomes mottled gray, yellow, and red, acid clay, having about the same physical characteristics as the layer above. The material continues to a depth of more than 5 feet and becomes slightly less compact with depth, but is distinctly mottled. Small angular fragments of shale, some of which are in different stages of weathering, are scattered over the surface and throughout the soil in various quantities.

\footnotetext{
${ }^{1}$ Respectively, Head Dept. of Soils, Assoc. Soil Conservationist, and two Jr. Soil Conservationists. This work was undertaken in cooperation with the Soil Conservation Service of Puerto Rico, of which Mr. E. A. Telford is Associate Soil Conservationist, and the Federal Experiment Station at Mayaguez.
} 
"Catalina clay" is one of the most extensive all-round farming soils in the humid uplands. The relief ranges from rolling to steep, but most of the hills are rounded and gently sloping ravines intervene. It is an acid soil, lateritic, derived from andesitic tuff and tuffaceous shale. A cultivated soil ranges in color from red to light brown. Few of the large fields are uniform in color, because deep plowing and sheet erosion have exposed the red subsoil that lies below the original brown or reddish-brown surface soil, and the result is a heterogeneous color. Normally, the surface soil is a light reddish-brown, friable, softly granular clay that forms large clods when plowed; but which soon slakes into fine granules after the first or second dashing tropical shower. The thickness of the surface soil, as well as the value of the land, varies with the relief. On the less valuable, steeper, more eroded slopes, the surface soil does not average more than 4 inches in thickness,

TABLE 1

Distances of planting of the leguminous crops

\begin{tabular}{l|l|c|c}
\hline \multicolumn{1}{c|}{ Crops } & Leguminosae & Between rows & Between plants \\
\cline { 2 - 3 } First & Velvet beans & 3 feet & inches \\
& Crotalaria & 14 inches & 18 \\
Cowpeas & 3 feet & Continuous \\
& Soybeans & 2.5 feet & 4 \\
Second & Velvet beans & 1 foot & 4 \\
& Crotalaria & 1 foot & 6 \\
& Cowpeas & 1 foot & 4 \\
& Soybeans & 1 foot & 4 \\
\hline
\end{tabular}

and when the land is plowed some of the subsoil is exposed. On the more rolling, more valuable, less eroded areas, the surface soil is generally about 8 inches thick. The upper part of the subsoil, ranging from a depth of 8 to 24 inches, is brownish-red or red heavy, but friable, slightly-granular clay. Both the surface soil and the subsoil are penetrated readily by plant roots and percolating water; and as a consequence, sheet erosion is less severe than on soils with more plastic subsoil, which absorb water more slowly. The lower part of the subsoil, beginning at a depth of about 24 inches, is a dark-red clay that is more friable than the material in the layers above. The uniform red clay continues to a depth ranging from 10 to 30 feet, before the parent rock is reached. Areas of "Catalina clay" in which the relief ranges from nearly level to slightly undulating, are classified as "Catalina clay", level phase. It has not been affected by sheet erosion, and the normal soil-forming processes have been acting unmolested on it for a long time. 
TABLE 2

Dates of planting and harvesting and age of crops

\begin{tabular}{|c|c|c|c|c|c|}
\hline Crops & Location & Leguminosae & $\begin{array}{l}\text { Date of } \\
\text { planting }\end{array}$ & $\begin{array}{c}\text { Date of } \\
\text { harvesting }\end{array}$ & Age \\
\hline \multirow{5}{*}{ First } & \multirow{5}{*}{ Río Piedras } & & 1944 & 1944 & days \\
\hline & & Velvet beans & June 21 & Sept. 6 & 77 \\
\hline & & Crotalaria & 8 & Aug. 14 & 67 \\
\hline & & Cowpeas & 26 & & 38 \\
\hline & & Soybeans & 21 & 16 & 56 \\
\hline \multirow[t]{4}{*}{ Second } & \multirow[t]{4}{*}{ Río Piedras } & Velvet beans & Oct. 6 & Dec. 7 & 62 \\
\hline & & Crotalaria & 26 & 11 & 46 \\
\hline & & Cowpeas & 16 & 6 & 51 \\
\hline & & Soybeans & 20 & & 46 \\
\hline \multirow[t]{4}{*}{ First } & \multirow[t]{4}{*}{ Mayaguez } & Velvet beans & May 29 & Sept. 5 & 103 \\
\hline & & Crotalaria & 30 & Aug. 4 & 66 \\
\hline & & Cowpeas & 29 & July 18 & 50 \\
\hline & & Soybeans & 30 & & 57 \\
\hline \multirow[t]{4}{*}{ Second } & \multirow[t]{4}{*}{ Mayaguez } & Velvet beans & Sept. 21 & Nov. 23 & 63 \\
\hline & & Crotalaria & Oct. 16 & poor growth & \\
\hline & & Cowpeas & Sept. 26 & Nov. 20 & 55 \\
\hline & & Soybeans & Oct. 9 & Nov. 21 & 43 \\
\hline
\end{tabular}

TABLE 3

Yields per acre of two consecutive crops of leguminosae in the absence or presence of lime and phosphoric acid

\begin{tabular}{|c|c|c|c|c|c|c|c|c|}
\hline \multirow{3}{*}{ Treatment } & \multicolumn{4}{|c|}{ Rio Piedras } & \multicolumn{4}{|c|}{ Mayaguez } \\
\hline & \multicolumn{2}{|c|}{ Field "A" } & \multicolumn{2}{|c|}{ Field "B" } & \multicolumn{2}{|c|}{ Field "A" } & \multicolumn{2}{|c|}{ Field "B" } \\
\hline & $\begin{array}{l}\text { First } \\
\text { crop }\end{array}$ & $\left|\begin{array}{c}\text { Second } \\
\text { crop }\end{array}\right|$ & $\begin{array}{l}\text { First } \\
\text { crop }\end{array}$ & $\begin{array}{l}\text { Second } \\
\text { crop }\end{array}$ & $\begin{array}{l}\text { First } \\
\text { crop }\end{array}$ & $\left|\begin{array}{c}\text { Second } \\
\text { crop }\end{array}\right|$ & $\begin{array}{c}\text { First } \\
\text { crop }\end{array}$ & $\mid \begin{array}{c}\text { Second } \\
\text { crop }\end{array}$ \\
\hline · & \multicolumn{4}{|c|}{ green weight } & \multicolumn{4}{|c|}{ green weight } \\
\hline & cwt. & covt. & cout. & cwt. & cwot. & cwt. & cwot. & covt. \\
\hline Velvet beans. & 93.1 & 89.6 & 126.9 & 111.4 & 94.8 & 63.0 & 54.2 & 34.7 \\
\hline Velvet beans with lime \& $\mathrm{P}_{2} \mathrm{O}_{5}$ & 125.6 & 113.3 & 135.3 & 133.0 & 126.3 & 98.9 & 86.8 & 60.8 \\
\hline Crotalaria.. & 33.0 & 6.8 & 84.4 & 10.1 & 29.1 & & 6.5 & \\
\hline Crotalaria with lime \& $\mathrm{P}_{2} \mathrm{O}_{5}$. & 41.3 & 10.3 & 117.3 & 7.4 & 31.2 & & 6.1 & \\
\hline Cowpeas............ & 96.2 & 97.0 & 69.9 & 92.3 & 81.7 & 60.7 & 51.9 & 24.4 \\
\hline Cowpeas with lime $\& \mathrm{P}_{2} \mathrm{O}_{5}$ & 96.0 & 106.2 & 94.8 & 122.8 & 89.3 & 72.1 & 67.5 & 30.3 \\
\hline Soybeans.......... & 16.6 & 25.1 & 38.9 & 30.7 & 43.2 & 22.4 & 22.6 & 12.6 \\
\hline \multirow[t]{3}{*}{ Soybeans with lime $\& \mathrm{P}_{2} \mathrm{O}_{5} \ldots \ldots \ldots$} & 24.9 & 40.2 & 53.9 & 48.7 & 88.0 & 35.6 & 41.5 & 16.4 \\
\hline & \multicolumn{4}{|c|}{ dry weight } & \multicolumn{4}{|c|}{ dry weight } \\
\hline & cwot. & cwot. & cwt. & cwet. & cwot. & cowt. & cwt. & cwot. \\
\hline Velvet beans. . & 20.4 & 18.2 & 27.0 & 22.2 & 17.2 & 12.6 & 12.7 & 9.1 \\
\hline Velvet beans with lime \& $\mathrm{P}_{2} \mathrm{O}_{5} \ldots$ & 26.8 & 22.9 & 28.5 & 24.6 & 22.4 & 19.9 & 19.4 & 16.2 \\
\hline Crotalaria........... & 4.7 & 1.2 & 11.9 & 1.6 & 5.0 & & 1.5 & \\
\hline Crotalaria with lime $\& \mathrm{P}_{2} \mathrm{O}_{5}$. & 5.9 & 2.3 & 16.2 & 1.2 & 5.3 & & 1.4 & \\
\hline Cowpeas............. & 9.4 & 13.4 & 7.1 & 13.0 & 12.3 & 10.7 & 9.2 & 5.4 \\
\hline Cowpeas with lime \& $\mathrm{P}_{2} \mathrm{O}$ & 9.7 & 14.9 & 9.3 & 17.1 & 13.5 & 13.1 & 12.2 & 6.8 \\
\hline Soybeans........... & 2.4 & 4.5 & 5.2 & 5.8 & 9.1 & 5.1 & 6.1 & 3.7 \\
\hline Soybeans with lime \& $\mathrm{P}_{2} \mathrm{O}_{5}$ & 3.8 & 7.4 & 7.6 & 9.2 & 18.7 & 8.5 & 9.8 & 5.1 \\
\hline
\end{tabular}


TABLE 4

Mean dry-weight yields per acre of all crops in Rio Piedras and Mayaguez, excluding Crotalaria

\begin{tabular}{|c|c|c|}
\hline Leguminosae & Treatment & General \\
\hline & cwt. & cwt. \\
\hline Velvet beans, no lime \& phosphorus......... & 17.42 & \\
\hline Velvet beans lime \& phosphorus............ & 22.58 & \\
\hline Velvet beans. . . . . . . . . . . . . . . . . . . . . & & 20.00 \\
\hline Cowpeas no lime \& phosphorus............. & 10.05 & \\
\hline Cowpeas, lime \& phosphorus.............. & 12.07 & \\
\hline 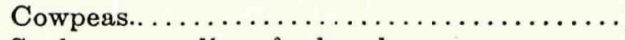 & & 11.06 \\
\hline Soybeans, no lime \& phosphorus............ & 5.25 & \\
\hline Soybeans, lime \& phosphorus............... & 8.76 & \\
\hline 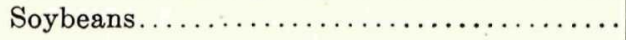 & & 7.01 \\
\hline
\end{tabular}

Values to be exceeded for significance by difference between means of:

\begin{tabular}{c|c}
\hline Treatments & General \\
\hline At $5 \%$ point; $1.967 \sqrt{\frac{2 \times 20.42}{72}}=1.48$ & $1.967 \sqrt{\frac{2 \times 20.42}{144}}=1.05$ \\
At $1 \%$ point; $2.590 \sqrt{\frac{2 \times 20.42}{72}}=1.95$ & $2.590 \sqrt{\frac{2 \times 20.42}{144}}=1.38$ \\
\hline
\end{tabular}

TABLE 5

Mean dry-weight yields per acre of all crops in Rio Piedras

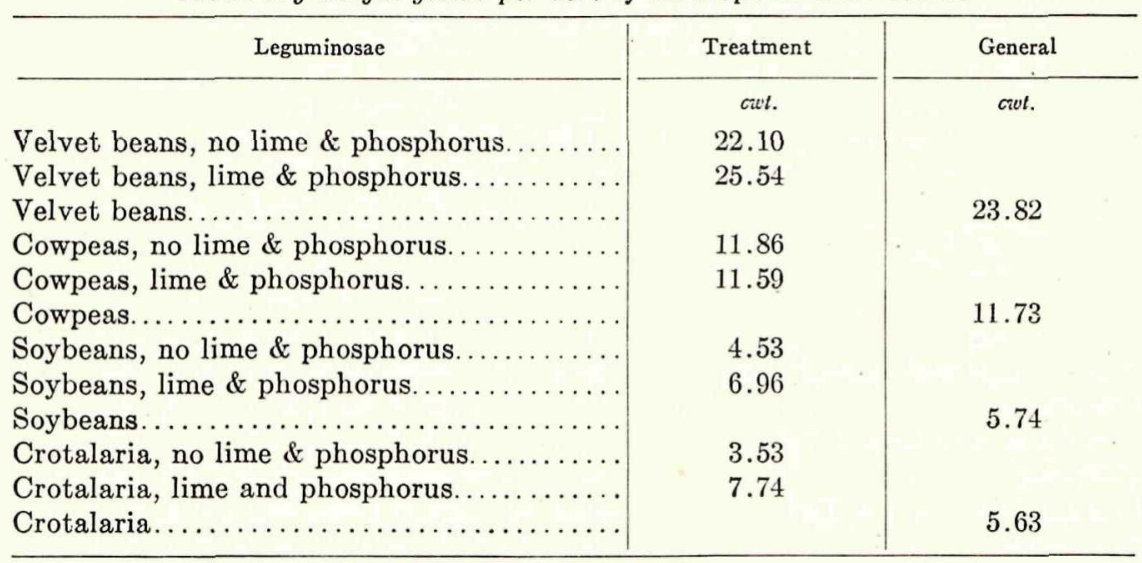

Values to be exceeded for significance by difference between means of:

\begin{tabular}{c|c}
\hline Treatments & General \\
\hline At $5 \%$ point; $1.971 \sqrt{\frac{2 \times 2.75}{36}}=0.77$ & $1.971 \sqrt{\frac{2 \times 2.75}{72}}=0.54$ \\
At $1 \%$ point; $2.599 \sqrt{\frac{2 \times 2.75}{36}}=1.02$ & $2.599 \sqrt{\frac{2 \times 2.75}{72}}=0.72$ \\
\hline
\end{tabular}


It differs from the typical soil, in that it has a thicker surface soil and a slightly more compact, lower subsoil layers; causing slightly restricted in-

TABLE 6

Analysis of the total sum of squared deviations, of the dry-weight for all crops of Leguminosae at Rio Piedras and Mayaguez, excluding the Crotalaria

\begin{tabular}{|c|c|c|c|c|}
\hline Source & $\begin{array}{c}\text { Degrees of } \\
\text { freedom }\end{array}$ & Sum of squares & Variance & $\mathrm{F}$ \\
\hline Zone.. & 1 & 499.66 & 499.66 & $16.14^{*}$ \\
\hline Field. . & 1 & 117.19 & 117.19 & 3.79 \\
\hline Zone $\mathrm{x}$ Field... & 1 & 910.02 & 910.02 & $29.40^{*}$ \\
\hline Crop................................ & 1 & 177.36 & 177.36 & $5.73^{*}$ \\
\hline Crop $x$ Field.............................. & 1 & .45 & .45 & \\
\hline Crop $x$ Zone. . . . . . . . . . . . & 1 & 732.16 & 732.16 & \\
\hline Crop x Zone x Field. . & 1 & .53 & .53 & t \\
\hline Error (a)........... & 64 & 1980.64 & 30.95 & \\
\hline Treatments. . & 5 & 14276.68 & 2855.34 & $39.83^{*}$ \\
\hline Species. $\ldots \ldots \ldots \ldots \ldots \ldots \ldots \ldots \ldots$ & 2 & 12731.07 & 636.55 & $31.17^{*}$ \\
\hline Fertilizer $\ldots \ldots \ldots \ldots \ldots \ldots \ldots \ldots \ldots \ldots$ & 1 & 1368.89 & 1368.89 & $67.04^{*}$ \\
\hline Species x Fertilizer................ & 2 & 176.72 & 88.36 & 3.05 \\
\hline Treatment $x$ Field. & 5 & 131.72 & 26.34 & \\
\hline Species $\times$ Field. & 2 & 72.63 & 36.31 & \\
\hline Fertilizer x Field........... & 1 & 9.54 & 9.54 & \\
\hline Species x Fertilizer Field... & 2 & 49.55 & 24.78 & \\
\hline Treatments x Crop. & 5 & 497.91 & 99.58 & $4.88^{*}$ \\
\hline Species x Crop........ & 2 & 473.77 & 236.88 & $11.60^{*}$ \\
\hline Fertilizer $\mathrm{x}$ Crop $\ldots \ldots \ldots \ldots \ldots \ldots$ & 1 & .50 & .50 & \\
\hline Species x Fertilizer x Crop..... & 2 & 23.64 & 11.82 & \\
\hline Treatments $\mathrm{x}$ Crop $\mathrm{x}$ Field.. & 5 & 22.00 & 4.40 & \\
\hline Species x Crop x Field. . & 2 & 13.07 & 6.54 & \\
\hline Fertilizer x Crop x Field............ & 1 & 1.01 & 1.01 & \\
\hline Species $\mathrm{x}$ Fertilizer $\mathrm{x}$ Crop $\mathrm{x}$ Field. & 2 & 7.92 & 3.96 & \\
\hline Total SS..................... & 431 & $\begin{array}{r}26288.50 \\
-19346.32\end{array}$ & & \\
\hline Error $(b), \ldots \ldots \ldots, \ldots \ldots \ldots, \ldots$ & 340 & 6942.18 & 20.42 & \\
\hline
\end{tabular}

* Significant at the $1 \%$ point.

ternal drainage which is reflected by the mottled gray, reddish-brown, and red coloring of the normally red lower subsoil layer.

Each one of the four experimental fields was divided into 72 plots, three with plots having an approximate area of one-hundredth acre; and one at Mayaguez, with plots having an approximate area of one-hundred twentieth 
acre. Half of the plots in each field received limestone at the rate of four tons per acre, and superphosphate at the rate of one-hundred pounds $\mathrm{P}_{2} \mathrm{O}_{5}$ per acre. Velvet beans Stizolobium deeringianum; crotalaria Crotalaria striata; cowpeas Vigna sinensis; and soybeans Soja max, Otootan variety;

TABLE 7

Analysis of the total sum of squared deviations of the dry-weight data for all four crops of Leguminosae at Rio Piedras

\begin{tabular}{|c|c|c|c|c|}
\hline Source & $\begin{array}{c}\text { Degrees of } \\
\text { freedom }\end{array}$ & Sum of squares & Variance & $\mathrm{F}$ \\
\hline Field. & 1 & 431.69 & 431.69 & $17.04 \dagger$ \\
\hline Crop.......... & 1 & 76.06 & 76.06 & 3.00 \\
\hline Crop x Field....................... & 1 & 109.51 & 109.51 & $4.32^{*}$ \\
\hline Error (a)..... & 32 & 811.02 & 25.34 & \\
\hline Treatments.... & 7 & 16270.61 & 2324.37 & $845.22 \dagger$ \\
\hline Species........ & 3 & 15786.11 & 5262.04 & $1754.00 \dagger$ \\
\hline Fertilizer. $\ldots \ldots \ldots \ldots \ldots \ldots \ldots \ldots$ & 1 & 438.08 & 438.08 & 146.00 \\
\hline Species $\mathrm{x}$ Fertilizer... & 3 & 46.42 & 15.47 & $5.63 \dagger$ \\
\hline Treatment $\mathrm{x}$ Field. & 7 & 292.01 & 41.72 & $15.17 \dagger$ \\
\hline Species x Field. & 3 & 206.47 & 68.82 & $25.03 \dagger$ \\
\hline Fertilizer $x$ Field. . & 1 & 0.00 & & \\
\hline Species $x$ Fertilizer $x$ Field............ & 3 & 85.54 & 28.51 & $10.37 \dagger$ \\
\hline Treatment x Crop. & 7 & 2049.87 & 292.84 & $106.49 \dagger$ \\
\hline Species $\mathrm{x}$ Crop....... & 3 & 2005.91 & 668.64 & $243.14 \dagger$ \\
\hline Fertilizer x Crop . ................. & 1 & 0.00 & & \\
\hline Species $\times$ Fertilizer $\mathrm{x}$ Crop....... & 3 & 43.96 & 14.65 & \\
\hline Treatm & 7 & 2786.21 & 398.03 & $144.74 \dagger$ \\
\hline Species x Crop x Field. . & 3 & 2619.80 & 873.27 & $317.55 \dagger$ \\
\hline Fertilizer $\mathrm{x}$ Crop $\mathrm{x}$ Field......... & 1 & 110.23 & 110.23 & $40.08 \dagger$ \\
\hline Species $\mathrm{x}$ Fertilizer $\mathrm{x}$ Crop $\mathrm{x}$ Field ..... & 3 & 56.18 & 18.73 & $6.81 \dagger$ \\
\hline 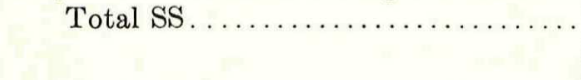 & 287 & $\begin{array}{r}23,442.18 \\
-22,826.98\end{array}$ & & \\
\hline Error (b). & 224 & 615.20 & 2.75 & \\
\hline
\end{tabular}

* Significant at the $5 \%$ point.

$\dagger$ Significant at the $1 \%$ point.

were selected for the Leguminosae. The seeds of soybeans at Río Piedras were inoculated with commercial Nitragin culture. All the other seeds were inoculated by the soil-paste or muddy-water method. Each treatment was replicated nine times.

Two consecutive crops of each one of the Leguminosae, planted at convenient distances (table 1) were harvested from each field (table 2). The 
first crops, except the velvet beans, were harvested at the preblooming period. The second crops were harvested at approximately the same dates.

Green-weight and dry-weight yields, for each one of the two crops of Leguminosae at Río Piedras and Mayaguez, are reported in table 3. Mean dryweight yields of all crops in Río Piedras and Mayaguez, excluding the crotalaria because of its poor growth in Mayaguez, are reported in table 4. Mean dry-weight yields of all crops in Río Piedras are reported in table 5.

Tables 6 and 7 contain, respectively, the analysis of the total sum of squared deviations of the mean dry weights.

\section{MAJOR RESULTS}

In general, the combined experiments at Río Piedras and Mayaguez, excluding the crotalaria (tables 4,6 ) indicate that:

1 - The mean dry-matter yield of velvet beans in the presence or absence of the lime and phosphorus application or as a whole, was significantly higher at the 1 per cent point, than that of cowpeas and soybeans; whereas that of cowpeas was higher than that of soybeans.

2-The mean dry-matter yield of velvet beans with lime and phosphorus, was significantly higher at the 1 per cent point, than that of velvet beans without lime and phosphorus. The same applies to soybeans, and cowpeas.

In general, the combined experiments at Río Piedras, including the crotalaria (tables 5, 7) indicate that:

1-The mean dry-matter yield of velvet beans in the presence or absence of lime and phosphorus application or as a whole, was significantly higher at the 1 per cent point, than that of cowpeas, soybeans, and crotalaria; whereas that of cowpeas was higher than that of soybeans, and crotalaria. The soybeans was significantly higher at the 5 per cent point, than the crotalaria, in the absence of lime and phosphorus, and significantly lower in their presence; but as a whole there was no significant mean difference between them.

2-The velvet beans, soybeans, and crotalaria, responded significantly at the 1 per cent point, to the application of lime and phosphorus. The cowpeas showed no response to the fertilizer.

\section{SUMMARY}

The effect of lime and phosphorus on the yields of velvet beans, crotalaria, cowpeas, and soybeans, is presented for eight crops harvested in the acid soil types Fajardo Clay and Catalina Clay, of Puerto Rico.

Data for distances of plantings, age of crops, green and dry-weight yields for each of two consecutive crops of the leguminosae in each of four fields, and for the mean dry-weight yields of all crops are presented. Analysis for the total sum of squared deviations of the dry weight for the various crops, is also presented and discussed. 
Velvet beans, the highest yielder, gave, in the absence or presence of lime and phosphorus, mean green weights of 83.5 and 110.0 hundredweights per acre, respectively, equivalent to mean dry weights of 17.4 and 22.6 hundred weights per acre.

\section{RESUMEN}

Se expone aquí el efecto de la cal y el fósforo en relacion con el rendimiento de las habichuelas "terciopelo", crotalarias, fréjoles y habas sojas de ocho cosechas, producidas en los tipos de suelos ácidos "Fajardo arcilloso" y "Catalina arcilloso" de Puerto Rico.

Se hace una exposición sobre la distancia de siembra, edad de las cosechas, rendimientos de dos cosechas consecutivas a base de peso verde y peso seco de las leguminosas de cada una de las cuatro fincas, así como del promedio de peso seco de todas las cosechas. Se expone y discute también el análisis de la suma total de las desviaciones cuadráticas del peso de las diversas cosechas a base de peso seco.

Las habichuelas "terciopelo", que fueron las que dieron mayor rendimiento, produjeron, en ausencia o presencia de la cal y el fósforo, un promedio de peso verde de 83.5 y 110.0 quintales por acre, respectivamente; equivalente a un promedio de peso seco de 17.4 y 22.6 quintales por acre. 


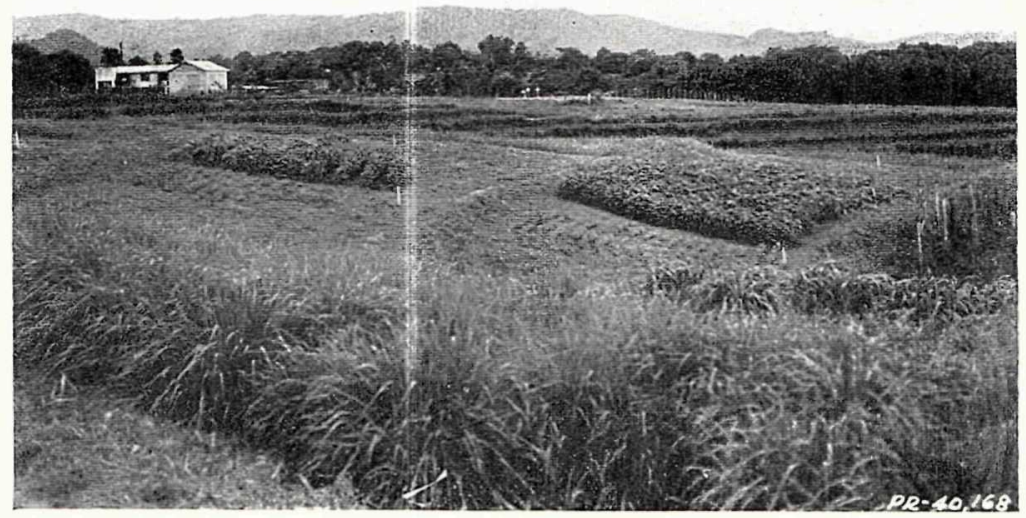

Fig. 1. General view of the legune plots as laid out on the contour at Mayaguez

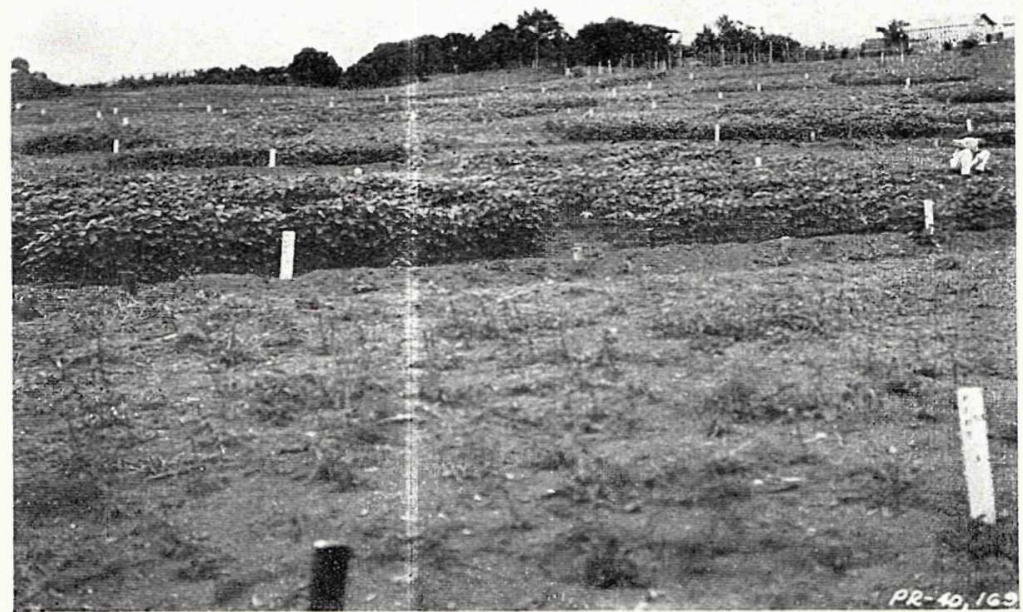

Fig. 2. Two adjacent soybe:n plots at Mayaguez. The plot at the left receivel lime and phosphorus 


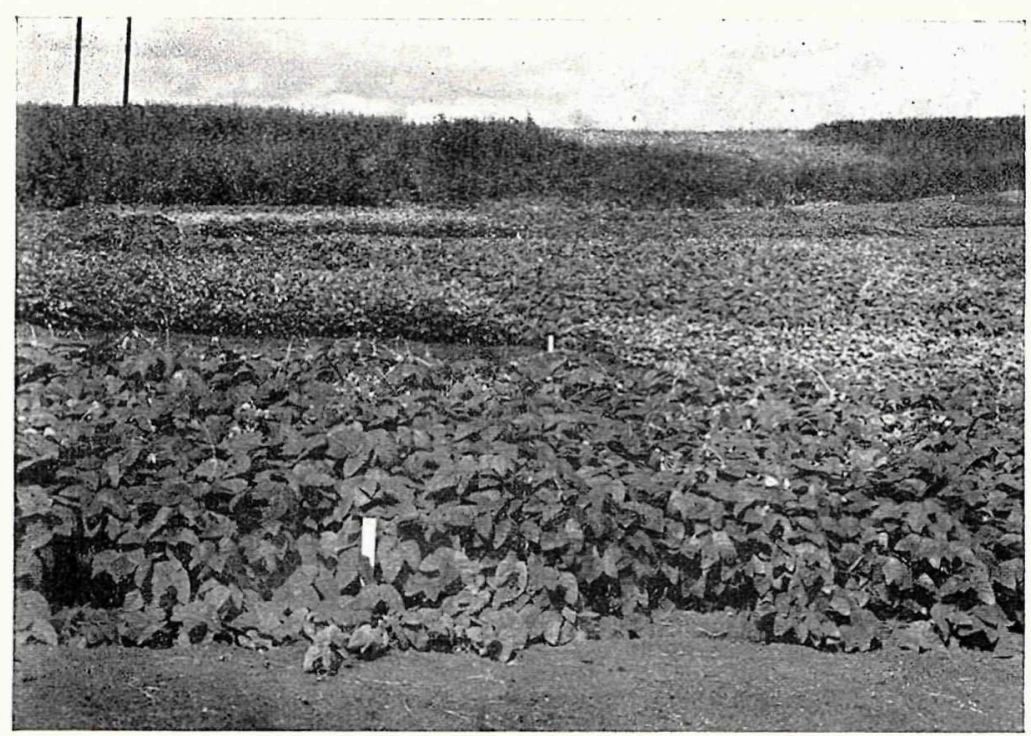

FIG. 3. Plot in foreground is one of velvet beans with lime and phosphorus, at Río Piedras

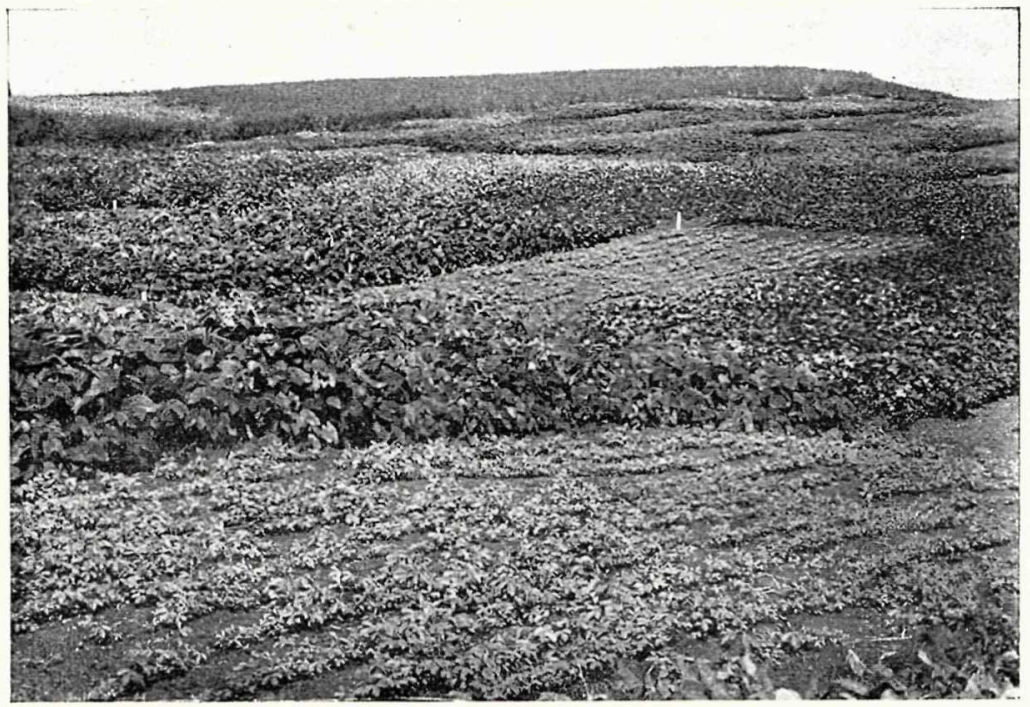

FIG. 4. General view of field at Rio Piedras. Crotalaria without lime and phosphorus in foreground and center. Velvet beans with lime and phosphorus in-between 